\title{
IMPLEMENTASI GREEN ACCOUNTING BERBASIS UNIVERSITY SOCIAL RESPONSIBILITY (USR) DI UNIVERSITAS NEGERI YOGYAKARTA
}

\author{
Widhiyanti Astiti \\ Prodi Akuntansi Universitas Negeri Yogyakarta \\ widhi.widhiwiwidhi.widhi@gmail.com
}

\begin{abstract}
Abstrak: Penelitian ini bertujuan untuk mengetahui implementasi green accounting berbasis university social responsibility (USR) di Universitas Negeri Yogyakarta. Populasi dalam penelitian ini adalah para pejabat di Universitas Negeri Yogyakarta yang berjumlah 325 orang. Teknik pengumpulan data pada penelitian ini adalah dokumentasi dan kuesioner. Desain penelitian ini adalah penelitian deskriptif. Jumlah sampel yang terkumpuk adalah 50 orang, Teknik pengambilan sampel yang digunakan adalah simple random sampling. Hasil penelitian ini menunjukan bahwa: 1) kepedulian lingkungan pada implementasi green accounting berbasis university social responsibility di UNY pada kecenderungan data kategori yang tinggi dengan presentase $50 \%$ atau sejumlah 25 responden. 2) keterlibatan lingkungan pada implementasi green accounting berbasis university social responsibility di UNY pada kecenderungan data kategori rendah yaitu sebesar 52\% atau mayoritas responden yaitu sebanyak 26 responden. 3) laporan lingkungan pada implementasi green accounting berbasis university social responsibility di UNY pada kecenderungan data kategori yang juga rendah, yaitu sebesar 21 responden atau 42\%. 4) audit lingkungan pada implementasi green accounting berbasis university social responsibility di UNY juga pada kecenderungan data kategori rendah, yaitu sebesar $44 \%$ atau 22 responden.
\end{abstract}

Kata Kunci: green accounting, university social responsibility (USR), kepedulian lingkungan, keterlibatan lingkungan, laporan lingkungan, audit lingkungan.

Abstract: The purpose of the research is to know about implementation of green accounting based university social responsibility at Yogyakarta State University. The population in this research were the officials at the State University of Yogyakarta, amount to 325 people . Data collection techniques in this study is the documentation and questionnaires. The research was a descriptive. The number of samples collected was 50 people, sampling technique used was simple random sampling. These results indicate that : 1 ) environmental concerns on the implementation of green accounting university -based social responsibility in UNY on the tendency of data categories with a high percentage of $50 \%$ or a number of 25 respondents . 2 ) involvement of the environment based on the implementation of green accounting in university social responsibility to the tendency of the data categories UNY low at $52 \%$ or a majority of respondents as many as 26 respondents . 3 ) environmental report on the implementation of green accounting university -based social responsibility in UNY on the tendency of data categories is also low at 21 respondents or $42 \%$. 4 ) environmental audits on the implementation of green accounting university -based social responsibility in UNY also the tendency of category data low at $44 \%$ or 22 respondents .

Keywords: green accounting, university social responsibility ( USR ), environmental awareness, environmental involvement, environmental reports , environmental audit.. 


\section{JURNAL NOMINAL / VOLUME III NOMOR 2 / TAHUN 2014}

\section{PENDAHULUAN}

Isu-isu mengenai lingkungan mulai banyak dibicarakan dekade terakhir. Masyarakat mulai sadar betapa pentingnya kelestarian lingkungan untuk kelangsungan hidup manusia dimasa depan. Isu-isu lingkungan langsung maupun tidak langsung mempengaruhi kegiatan bisnis pada suatu organisasi. Hal ini tentu memaksa kegiatan bisnis perusahaan untuk menyesuaikan diri terhadap isu lingkungan. Bentuk penyesuaian kegitan bisnis perusahaan terhadap isu lingkungan adalah akuntansi. Akuntansi sebagai calculate science yaitu akuntansi menerapkan perhitungan biaya lingkungan dalam implementasi ilmunya untuk tujuan transparasi perusahaan dalam mengungkapkan informasi lingkungan sebagai dampak dari aktivitas bisnis yang dilakukan perusahaan (Lisa Kartikasari, 2012: 1). Ilmu akuntansi yang mempelajari khusus di bidang lingkungan disebut dengan green accounting atau juga dikenal dengan enviromental accounting.

Perkembangan akuntansi lingkungan sendiri dimulai sekitar pertengahan tahun 1990 dimana Internasional Accounting Standars Committee atau IASC mengembangkan konsep mengenai akuntansi lingkungan dan audit hak asasi manusia. Setelah itu standar industri mengenai akuntansi lingkungan mulai berkembang dan auditor profesional mulai mengeluarkan prinsip-prinsip tentang audit lingkungan (Lisa Kartikasari, 2012: 3). Di Jepang, Mei tahun 2000 The Environmental Ageency atau Badan Lingkungan Hidup mengeluarkan panduan akuntansi lingkungan yang kemudian disempurnakan pada tahun 2002 dan 2005 dan mewajibkan seluruh perusahaan negara tersebut untuk menerapkan akuntansi lingkungan. Dan sekarang, akuntansi lingkungan di Jepang sama pentingnya dengan akuntansi konvensional (Lisa Kartikasari, 2012: 3).

Pengertian Akuntansi lingkungan menurut United States Environment Protection Agency (US-EPA), Green Accounting is identifying and measuring the cost of environmental materials and activities and using this information for environmental management decisions. The purpose is to recognize and seek to mitigate the negative environmental effects of activities and sistems (Memorandum USEPA, 1995: 20). Dijelaskan pula, US-EPA membagi istilah akuntansi lingkungan menjadi dua dimensi utama, yaitu yang pertama adalah akuntansi lingkungan merupakan biaya yang langsung berdampak pada perusahaan secara menyeluruh. Kedua, akuntansi lingkungan merupakan biaya individu, masyarakat maupun lingkungan suatu perusahaan yang tidak dapat dipertanggungjawabkan.

Akuntansi lingkungan berbasis Corporate Social Responsibility (CSR) sudah banyak di implementasikan 


\section{JURNAL NOMINAL / VOLUME III NOMOR 2 / TAHUN 2014}

perusahaan-perusahaan besar sebagai bentuk tanggungjawab perusahaan atas dampak lingkungan terhadap kegiatan bisnis yang dilakukannya. Bentuk CSR di Perguruan Tinggi dikenal dengan University Social Responsibility atau disingkat USR. Definisi USR dijelaskan dalam penelitian Maylia Pramono Sari dan Paulus Basuki Hadiprajitno adalah Universiy Social Responsibility pada dasarnya merupakan suatu kebijakan etis yang mempengaruhi kualitas kinerja komunitas perguruan tinggi yang meliputi mahasiswa, pengelola, pengajar, dan seluruh karyawan perguruan tinggi melalui manajemen pertanggungjawaban terhadap dampak pendidikan, kognitif, ketenagakerjaan, dan lingkungan yang dihasilkan oleh perguruan tinggi melalui suatu dialog interaktif dengan masyarakat dalam rangka menghasilkan pembangunan manusia yang berkesinambungan (Maylia Pramono Sari dan Paulus Basuki Hadiprajitno, 2013: 178).

Di Indonesia standar akuntansi yang dipakai sebagai acuan belum mewajibkan perguruan tinggi untuk mengungkapkan informasi sosial yang berkaitan dengan kegiatan yang dilaksanakan, khususnya dalam tanggungjawab perguruan tinggi terhadap dampak lingkungan akibat dari kegiatan yang dilakukan. Ketidakwajiban ini menyebabkan pihak perguruan tinggi akan mempertimbangkan manfaat dan kerugian yang akan diperoleh sebelum memutuskan untuk mengungkapkan informasi sosial tersebut. Pihak perguruan tinggi akan mengungkapkan informasi sosial apabila manfaat pengungkapkan informasi sosial tersebut dinilai lebih besar dibandingkan kerugiannya. Namun alangkah bijaksana apabila pihak perguruan tinggi tidak hanya mementingkan kepentingan internal semata, namun kepentingan pihak-pihak lain seperti mahasiswa, karyawan, dosen, dan masyarakat yang terkena dampak lingkungan dan sosial kegiatan perguruan tinggi baik secara langsung maupun tidak langsung juga harus diperhatikan dan ikut diperhitungkan.

Dalam penelitian Teoh dan Thong (1986) dalam Yousef (2003) bahwa suatu organisasi dapat dikategorikan ikut andil dalam menjaga lingkungan hidup jika memiliki perhatian terhadap lingkungan hidup (Environmental awareness) itu sendiri, yang selanjutnya diikuti dengan keterlibatan organisasi tersebut terhadap permasalahan lingkungan (Environmental Involvement). Hal ini perlu diikuti dengan pelaporan lingkungan (Environmental Reporting), terutama kinerja organisasi dalam mengatasi dampak kegiatan organisasi terhadap lingkungan, yang kemudian disempurnakan dengan kegiatan audit lingkungan (Environmental Auditing) untuk mengukur dan mengevaluasi kinerja organisasi. Oleh karena itu dapat disimpulkan setidaknya diperlukan empat 
faktor dalam hal tanggungjawab organisasi terhadap lingkungan adalah kepedulian lingkungan, keterlibatan lingkungan, laporan lingkungan, dan audit lingkungan.

Menurut Joko Susilo (2008: 154) dan penelitian Maylia Pramono Sari dan Paulus Basuki Hadiprajitno (2013: 179) tahapan perguruan tinggi untuk menerapkan Green Accounting berbasis University Social Responsibility adalah:

a. Environmental awareness

Hal pertama yang dilakukan perguruan tinggi dalam perencanaannya mengimplementasikan Green Accounting berbasis University Social Responsibility adalah membangun kesadaran dan komitmen pentingnya USR. Pada variabel ini yang diteliti adalah kondisi-kondisi yang menyebabkan responden perhatian pada masalah lingkungan hidup.

b. Environmental Involvement

Langkah selanjutnya adalah tata cara implementasi penerapan Green Accounting berbasis USR dimana dilakukan dengan tim khusus yang dibentuk langsung berada di bawah pengawasan pimpinan perguruan tinggi yang ditunjuk dan melakukan evaluasi pelaksanaan serta mengukur ke efektivitas penerapan.

c. Environmental Reporting

Pelaporan lingkungan diperlukan untuk proses pengambilan keputusan maupun dalam rangka keperluan keterbukaan informasi material dan relevan mengenai perguruan tinggi. Pada variabel ini diukur berdasarkan jawaban atas ketersediaan laporan kinerja lingkungan hidup entitas.

\section{d. Environmental Auditing}

Langkah terakhir adalah untuk memastikan apakah kinerja progam konservasi lingkungan hidup yang dilakukan sudah berjalan efektif dan efisien diperlukan audit kinerja lingkungan. Variabel yang terakhir ini diukur berdasarkan jawaban atas ketersediaan laporan audit kinerja lingkungan hidup perguruan tinggi.

Sudah banyak perguruan tinggi yang mulai sadar mengenai USR, contohnya seperti Universitas Negeri Semarang yang telah dikukuhkan sebagai Universitas Konservasi yang mengimplementasikan USR untuk mewujudkan Good University Governance. Di Universitas Negeri Yogyakarta (UNY) pihak kampus mulai sadar pentingnya lingkungan sebagai penunjang pembelajaran di kampus. Bentuk kesadaran lingkungan oleh pihak kampus antara lain adalah penghijauan di lingkungan kampus, mulai tersedia parkir khusus pengguna sepeda, kegiatan-kegiatan kampus yang berhubungan dengan lingkungan. Namun, sangat disayangkan karena kesadaran Universitas Negeri 


\section{JURNAL NOMINAL / VOLUME III NOMOR 2 / TAHUN 2014}

Yogyakarta akan tanggungjawab sosial di lingkungan kampusnya belum sepenuhnya diwujudkan. Beberapa kalangan mahasiswa dan karyawan mengeluhkan masalah lingkungan, yang antara lain adalah kurangnya tempat sampah sehingga Universitas Negeri Yogyakarta sering terlihat kotor karena sampah yang dibuang sembarangan. Selain itu, mahasiswa juga mengeluhkan kebersihan kelas yang menjadi sarang nyamuk, sehingga sangat menggangu kenyamanan saat kegiatan belajar mengajar. Fasilitas penunjang belajar bagi mahasiswa beberapa ada yang kurang terawat, seperti misalnya adalah kolam renang FIK yang terlihat kotor, rusak lantainya, dan banyak coretan di tembok. Fasilitas tempat parkir di UNY dinilai sangat kurang, Fakultas Ilmu Sosial dan contohnya, tempat parkir mahasiswa terlihat tidak rapi dan panas, tempat parkir Fakultas Ekonomi dan Fakultas Matematika dan Ilmu Pengetahuan Alam juga tidak jauh berbeda. Timbulnya semua permasalahan tersebut tentu menimbulkan pertanyaan apakah Universitas Negeri Yogyakarta memiliki perhatian dan kepedulian khusus di bidang lingkungan sebagai bentuk tanggungjawab sosial dan lingkungannya? Dan apakah Universitas Negeri Yogyakarta memiliki laporan keuangan dan kegiatan audit lingkungan sebagai salah satu bentuk laporan dan kontrol dari dalam pihak kampus? Tujuan penelitian ini sendiri

adalah untuk mengethaui implementasi green accounting berbasis university social responsibility di Universitas Negeri Yogyakarta.

\section{METODE PENELITIAN}

\section{Jenis Penelitian}

Penelitian ini merupakan penilitian deskriptif kuantitatif yang menggambarkan keadaan serta fenomena suatu objek disertai data statistic melalui data sampel.

\section{Waktu dan Tempat Penelitian}

Penelitian dilakukan di Universitas Negeri Yogyakarta dengan waktu pelaksanaan peenlitian adalah bulan Januari sampai dengan bulan Febuari 2014.

\section{Populasi dan Sampel Penelitian}

Populasi yang diambil peneliti adalah para pejabat di Universitas Negeri Yogyakarta dengan jumlah total adalah 325 orang. Dari 325 orang tersebut peneliti mengambil sampel dengan metode yang digunakan Isaac dan Michael untuk tingkat kesalahan 10\%, sehingga didapat jumlah sampel adalah 147 orang. Teknik pengambilan sampel adalah dengan menggunakan teknik simple random sampling, yaitu mengambil sampel secara acak tanpa memperhatikan strata. 
JURNAL NOMINAL / VOLUME III NOMOR 2 / TAHUN 2014

Data, Instrumen, dan Teknik Pengumpulan Data

\begin{tabular}{lll}
\hline C & 3 & $\begin{array}{l}\text { Responden tidak tahu } \\
\text { mengenai item tersebut. }\end{array}$ \\
\hline D & 4 & $\begin{array}{l}\text { Responden setuju jika } \\
\text { item itu ada di instansi } \\
\end{array}$ \\
& kerjanya. \\
\hline E & 5 & Responden setuju dan \\
& & secara rill ada di intansi \\
& kerjanya.
\end{tabular}
tanggungjawab dalam mengelola lingkungan hidup disekitar kampus yang diukur berdasarkan seperti penelitian Teoh dan Thong (1986) dalam Yousef (2003) dimana terdapat empat aspek lingkungan : kesadaran lingkungan (Environmental awareness), keterlibatan lingkungan (environmental involvement), pelaporan lingkungan (enviromental reporting), dan audit lingkungan (environmental auditing). Variabel diukur dengan model skala Likert yang mengukur sikap dan kondisi rill yang dinyatakan dengan angka satu sampai dengan lima.

Tabel 1. Skala Likert

\begin{tabular}{ccl}
\hline $\begin{array}{c}\text { Pilihan } \\
\text { Jawaban }\end{array}$ & Skor & \multicolumn{1}{c}{ Makna } \\
\hline A & 1 & $\begin{array}{l}\text { Responden tidak setuju } \\
\text { dan secara rill item itu } \\
\end{array}$ \\
& & tidak ada di intansi \\
& kerjanya. \\
\hline B & 2 & Responden tidak setuju \\
& & jika item itu ada di \\
& & instansi kerjanya.
\end{tabular}

Kisi-kisi intrumen penelitian Implementasi Green Accounting berbasis University Social Responsibility (USR) di Universitas Negeri Yogyakarta adalah sebagai berikut :

\section{Environmental awareness}

Hal pertama yang dilakukan perguruan tinggi dalam perencanaannya mengimplementasikan Green Accounting berbasis University Social Responsibility adalah membangun kesadaran dan komitmen pentingnya USR. Pada variabel ini yang diteliti adalah kondisi-kondisi yang menyebabkan responden perhatian pada masalah lingkungan hidup. Kondisi yang akan disajikan dalam kuesioner untuk menilai green accounting berbasis USR adalah:

a. Adanya peraturan mengenai lingkungan hidup

b. Filosofi dari pimpinan perguruan tinggi 


\section{JURNAL NOMINAL / VOLUME III NOMOR 2 / TAHUN 2014}

c. Adanya sugesti dari asosiasi perguruan tinggi lain

d. Adanya sugesti dari diri sendiri

e. Adanya sugesti dari karyawan

f. Adanya sugesti dari mahasiswa

g. Adanya sugesti dari lembaga lingkungan hidup

h. Adanya sugesti dari komunitas lingkungan

i. Adanya dukungan Sumber Daya Manusia (SDM) dan Sumber Daya Ekonomi (SDE).

j. Adanya dukungan rencana induk penelitian dan pengabdian masyarakat

k. Terdapat realisasi penelitian dan pengabdian masyarakat

\section{Environmental Involvement}

Langkah selanjutnya adalah tata cara implementasi penerapan Green Accounting berbasis USR dimana dilakukan dengan tim khusus yang dibentuk langsung berada di bawah pengawasan pimpinan perguruan tinggi yang ditunjuk dan melakukan evaluasi pelaksanaan serta mengukur ke efektivitas penerapan. Untuk mengukur keterlibatan lingkungan di perguruan tinggi, menurut Teoh dan Thong (1986) dalam Yousef (2003) adalah:

a. Keberadaan unit lingkungan hidup dalam perguruan tinggi

b. Ketersediaan dana untuk perlindungan lingkungan hidup

c. Ketersediaan progam atau prosedur yang mengurangi konsumsi sumber daya alam

d. Ketersediaan studi keselamatan lingkungan hidup jika entitas menggunakan mesin-mesin dalam kegiatan operasionalnya

\section{Environmental Reporting}

Pelaporan lingkungan diperlukan untuk proses pengambilan keputusan maupun dalam rangka keperluan keterbukaan informasi material dan relevan mengenai perguruan tinggi. Pada variabel ini diukur berdasarkan jawaban atas ketersediaan laporan kinerja lingkungan hidup entitas yang meliputi (Dunk, 2002: 719-732):

a. Laporan kinerja lingkungan hidup

b. Laporan kinerja dilaporkan secara kontiyu

c. Laporan kinerja dipublikasikan

d. Laporan kinerja lingkungan hidup melampiri publikasi

\section{Environmental Auditing}

Langkah terakhir adalah untuk memastikan apakah kinerja progam konservasi lingkungan hidup yang dilakukan sudah berjalan efektif dan efisien diperlukan audit kinerja lingkungan. Variabel yang terakhir ini diukur berdasarkan jawaban atas ketersediaan laporan audit kinerja lingkungan hidup perguruan tinggi yang meliputi: 
a. Terdapat laporan audit mengenai green accounting di perguruan tinggi

b. Terdapat satuan pengawas internal (SPI) mengenai green accounting di perguruan tinggi

Pada penelitian ini, data diperoleh dengan dua cara, yaitu:

1. Dokumentasi

Teknik dokumentasi pada penelitian ini adalah pengumpulan data yang diperoleh dari catatan-catatan, laporan-laporan, serta dokumen-dokumen yang terdapat di Universitas Neheri Yogyakarta terkait akuntansi lingkungan berbasis USR.

2. Kuesioner

Kuesioner digunakan untuk pengumpulan data primer yang diperoleh dari jawaban-jawaban responeden terkait perhatian, keterlibatan, pelaporan akuntansi lingkungan, dan audit akuntansi lingkungan berbasis USR. Jenis kuesioner adalah kuesioner tertutup dimana didalam kuesioner sudah disediakan jawaban sehingga responden hanya memilih yang dinyatakan dalam skala likert 1 sampai 5.

\section{Teknik Analisis Data}

Teknik analisis yang digunakan dalam penelitian ini adalah analisis deskriptif yang berfokus pada penyebab munculnya perhatian dari pimpinan unit terhadap permasalahan lingkungan hidup, kondisi apa

yang paling mempengaruhi masing-masing pimpinan universitas untuk perhatian terhadap permasalahan lingkungan, dan seberapa besar perhatian tersebut. Begitu juga dengan keterlibatan lingkungan, pelaporan lingkungan, dan audit lingkungan juga akan dinilai di analisis deskriptif ini.

\section{HASIL PENELITIAN DAN PEMBAHASAN}

Penelitian ini dilaksanakan pada bulan Januari sampai bulan Febuari 2014. Data pada penelitian ini dikumpulkan dengan cara menyebar kuesioner. Kuesioner disebar sejumlah sampel yaitu 147 kuesioner dengan tingkat pengembalian $35,37414966 \%$ yaitu sejumlah 52 kuesioner. Berikut rincian jumlah pengembalian kuesioner:

Tabel 2. Distribusi Kuesioner

\begin{tabular}{cc}
\hline Keterangan & $\begin{array}{c}\text { Jumlah } \\
\text { Responden }\end{array}$ \\
\hline Kuesioner disebar & 147 \\
Kuesioner kembali & 52 \\
Tidak lengkap & 2 \\
\hline Jumlah yang bisa diolah & 50 \\
\hline Sumber: Data diolah &
\end{tabular}

Hasil Penelian

Kepedulian lingkungan (Environmental awareness) terkait implementasi green accounting berbasis university social 
responsibility di Universitas Negeri Yogyakarta.

Data yang telah diperoleh dari kuesioner digolongkan kedalam kategori kecenderungan kepedulian lingkungan yang dibedakan menjadi lima kategori, yaitu kategori sangat tinggi, kategori tinggi, kategori sedang, kategori rendah, dan kategori sangat rendah. Berikut adalah tabel kategori kecenderungan kepedulian lingkungan:

Tabel 3. Kategori kecenderungan kepedulian lingkungan

\begin{tabular}{ccccc}
\hline No & Kategori & Interval & Frek & $\begin{array}{c}\text { Frek. } \\
\text { relative }\end{array}$ \\
\hline 1 & $\begin{array}{l}\text { Sangat } \\
\text { tinggi }\end{array}$ & $33<X$ & 19 & $38 \%$ \\
2 & Tinggi & $27<X$ & 25 & $50 \%$ \\
& & $\leq 33$ & & \\
3 & Sedang & $21<X$ & 4 & $8 \%$ \\
& & $\leq 27$ & & \\
4 & Rendah & $15<X$ & 2 & $4 \%$ \\
& & $\leq 21$ & & \\
5 & Sangat & $6<X$ & 0 & $0 \%$ \\
& rendah & $\leq 15$ & & \\
\hline \multicolumn{7}{l}{ Total } & & 50 & $100 \%$
\end{tabular}

Sumber : data diolah
Environmental

Awareness

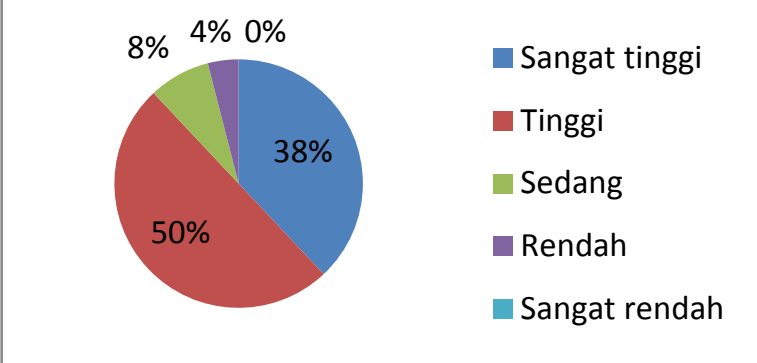

Gambar 1. Pie Chart Kategori kecenderungan kepedulian lingkungan

Dari tabel 3 dapat dilihat bahwa kategori kepedulian lingkungan mayoritas adalah tinggi dengan presentase $50 \%$ atau sejumlah 25 responden.

Keterlibatan lingkungan (Environmental Involvement) terkait implemenatsi green accounting berbasis university social responsibility di Universitas Negeri Yogyakarta.

Data yang diperoleh digolongkan ke dalam kategori kecenderungan keterlibatan lingkungan yang dibagi menjadi lima yaitu kategori sangat tinggi, tinggi, sedang, rendah, dan sangat rendah. Berikut adalah tabel kategori kecenderungan keterlibatan lingkungan. 
Tabel 4. Kategori kecenderungan keterlibatan lingkungan

\begin{tabular}{|c|c|c|c|c|}
\hline No & Kategori & Interval & Frek. & $\begin{array}{l}\text { Frek. } \\
\text { Relatif }\end{array}$ \\
\hline 1 & $\begin{array}{l}\text { Sangat } \\
\text { tinggi }\end{array}$ & $\begin{array}{l}45<X \\
\leq 57\end{array}$ & 1 & $2 \%$ \\
\hline 2 & Tinggi & $\begin{array}{l}37<X \\
\leq 45\end{array}$ & 2 & $4 \%$ \\
\hline 3 & Sedang & $\begin{array}{l}29<X \\
\leq 37\end{array}$ & 9 & $18 \%$ \\
\hline 4 & Rendah & $\begin{array}{l}21<X \\
\leq 29\end{array}$ & 26 & $52 \%$ \\
\hline 5 & $\begin{array}{l}\text { Sangat } \\
\text { rendah }\end{array}$ & $\begin{array}{l}9<X \\
\leq 21\end{array}$ & 12 & $24 \%$ \\
\hline
\end{tabular}

Sumber : data diolah

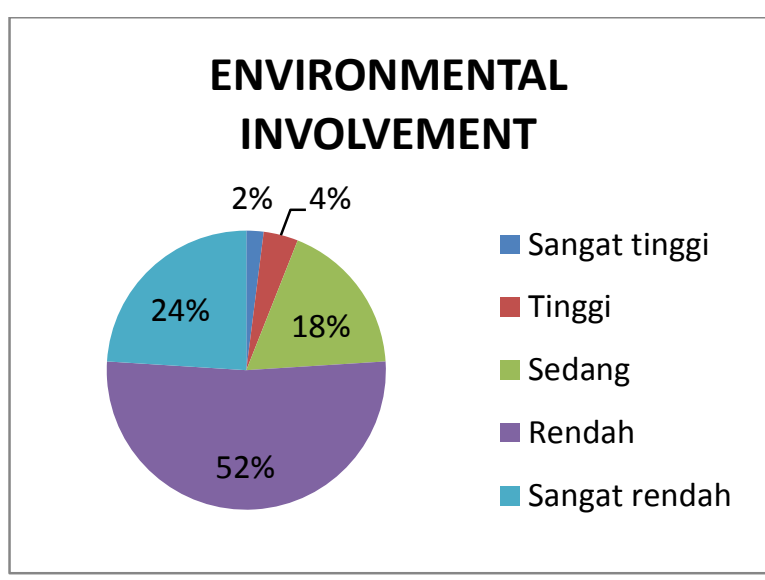

Gambar 2. Pie Chart Kecenderungan keterlibatan lingkungan

Keterlibatan lingkungan pada tabel 4 mayoritas masuk dalam kategori rendah dengan jumlah responden 26 responden.
Laporan Lingkungan (Environmental Reporting) terkait implemenatsi green accounting berbasis university social responsibility di Universitas Negeri Yogyakarta.

Data yang sudah didapat kemudian diolah untuk digolongkan kedalam lima kategori. Yang dibagi menjadi sangat tinggi, tinggi, sedang, rendah, dan sangat rendah. Berikut adalah tabel kategori kecenderungan pelaporan lingkungan:

Tabel 5. Kategori Kecenderungan Pelaporan lingkungan

\begin{tabular}{lllcc}
\hline No & Kategori & Interval & Frek. & $\begin{array}{l}\text { Frek. } \\
\text { Relatif }\end{array}$ \\
\hline 1 & Sangat & $16,5<X$ & 2 & $4 \%$ \\
& tinggi & $\leq 21$ & & \\
2 & Tinggi & $13,5<X$ & 2 & $4 \%$ \\
& & $\leq 16,5$ & & \\
3 & Sedang & $10,5<X$ & 19 & $38 \%$ \\
& & $\leq 13,5$ & & \\
4 & Rendah & $7,5<X$ & 21 & $42 \%$ \\
& & $\leq 10,5$ & & \\
5 & Sangat & $3<X$ & 6 & $12 \%$ \\
& rendah & $\leq 7,5$ & & \\
\hline \multicolumn{7}{l}{ Total } & & 50 & $100 \%$ \\
\hline
\end{tabular}

Sumber: data diolah 


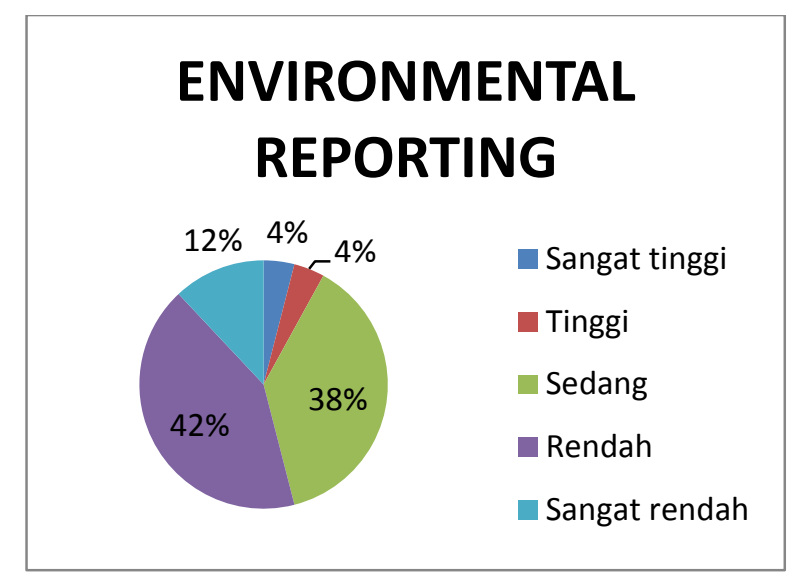

Gambar 3. Pie Chart Kecenderungan

Pelaporan Lingkungan

Tabel 5 menunjukan kecenderungan data berada pada kategori rendah yaitu 21 responden $(42 \%)$.

\section{Audit Lingkungan (Environmental} Auditing) terkait implemenatsi green accounting berbasis university social responsibility di Universitas Negeri Yogyakarta.

Data tersebut kemudian digolongkan kedalam kategori kecenderungan audit lingkungan yang dibedakan menjadi lima kategori, yaitu audit lingkungan sangat tinggi, audit lingkungan tinggi, audit lingkungan sedang, audit lingkungan rendah, dan audit lingkungan sangat rendah. Berikut adalah tabel distribusi kecenderungan audit lingkungan:
Tabel 6. Kategori Kecenderungan Audit lingkungan

\begin{tabular}{ccccc}
\hline No & Kategori & Interval & Frek. & $\begin{array}{l}\text { Frek. } \\
\text { Relatif }\end{array}$ \\
\hline 1 & Sangat & 16,5 & 2 & $4 \%$ \\
& tinggi & $<X$ & & \\
& & & & \\
2 & Tinggi & 13,5 & 7 & $14 \%$ \\
& & $<X$ & & \\
& & & & \\
3 & Sedang & 10,5 & 15 & $30 \%$ \\
& & $<X$ & & \\
& & $\leq 13,5$ & & \\
4 & Rendah & $7,5<X$ & 22 & $44 \%$ \\
& & $\leq 10,5$ & & \\
\multirow{3}{*}{5} & Sangat & $3<X$ & 4 & $8 \%$ \\
& rendah & $\leq 7,5$ & &
\end{tabular}

\begin{tabular}{lll}
\hline Total & $50 \quad 100 \%$ \\
\hline
\end{tabular}

Sumber: data diolah

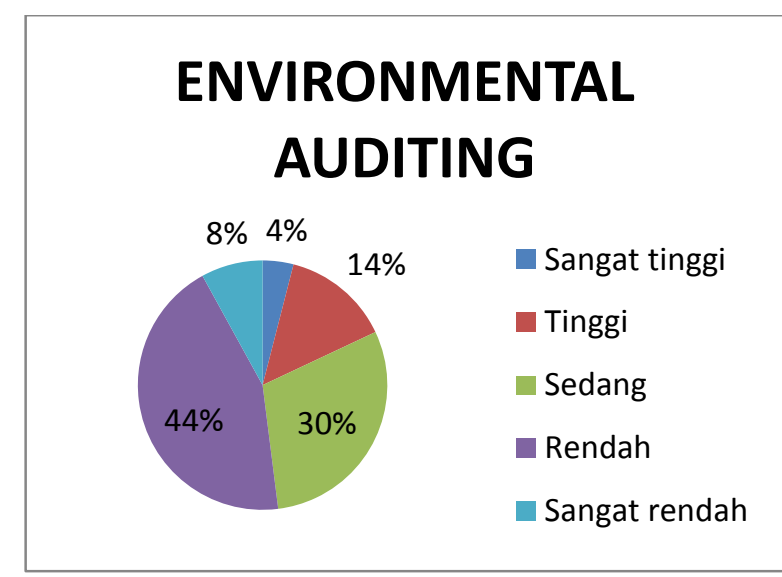

Gambar 4. Pie Chart Kecenderungan Audit Lingkungan

Dapat dilihat pada tabel 6 kecenderungan data pada audit lingkungan berada pada 


\section{JURNAL NOMINAL / VOLUME III NOMOR 2 / TAHUN 2014}

kategori rendah dengan 22 responden dan presentase $44 \%$.

\section{Pembahasan}

Hasil dari penelitian ini adalah Universitas Negeri Yogyakarta memiliki kepedulian terhadap lingkungan yang tinggi. Namun sangat disayangkan kepedulian UNY terhadap lingkungan berbanding terbalik dengan keterlibatan UNY terhadap lingkungan. Kepedulian lingkungan yang tinggi ini tidak direalisasikan dengan keterlibatan lingkungan oleh pihak Universitas Negeri Yogyakarta. Begitupula dengan pelaporan lingkungan dan audit lingkungan di UNY yang masih dikategorikan rendah. Berikut adalah hasil penelitian terkait empat aspek lingkungan green accounting berbasis university social responsibility di Universitas Negeri Yogyakarta:

\section{Kepedulian lingkungan (environmental awareness)}

Tahap pertama yang harus dilakukan perguruan tinggi dalam perencanaanya mengimplementasikan Green Accounting adalah membangun kesadaran dan komitmen pentingnya University Social Responsibility. Pimpinan di Universitas Negeri Yogyakarta setuju dan mendukung apabila terdapat peraturan mengenai lingkungan hidup dan USR di UNY. Pimpinan Universitas Negeri Yogyakarta memiliki filosofi mengenai lingkungan hidup. Hal ini sesuai fakta yang terdapat di lapangan dengan dibuktikannya komitmen UNY untuk menegakan good governance university dan jargon baru di UNY "green and clean university". Universitas Negeri Yogyakarta sadar mengenai pentingnya lingkungan. Dibuktikan dengan fasilitasfasilitas yang dibangun dengan mengedepankan penghijauan. Selain itu, pada buku panduan Universitas Negeri Yogyakarta juga mulai dibahas mengenai kampus hijau yang peduli lingkungan. Di Universitas Negeri Yogyakarta beberapa dosen serta karyawan mulai sadar akan lingkungan. seperti di Fakultas Teknik misalnya, dekan fakultas sangat antusias dengan proyek mobil listrik yang dikembangkan mahasiswanya dengan alasan goo green. Beberapa dosen sadar dengan lingkungan dengan meminimalisir penggunaan kertas, dan beberapa waktu yang lalu pihak Fakultas Ekonomi bekerjasama dengan pihak pertamina untuk penananaman pohon di area fakultas. Pimpinan Universitas Negeri Yogyakarta setuju apabila di UNY terdapat anggaran khusus untuk lingkungan hidup dan USR. Selain itu pimpinan di UNY juga setuju apabila terdapat SDM yang secara khusus menangani masalah lingkungan hidup serta USR. Universitas Negeri Yogyakarta memiliki lembaga khusus mengenai rencana induk penelitian dan pengabdian 
masyarakat, yaitu Lembaga Penelitian dan Pengabdian kepada Mayarakat (LPPM). Di LPPM didukung oleh sembilan pusat penelitian dan pengembangan, salah satunya adalah Pusat Penelitian Budaya, Kawasan, dan Lingkungan Hidup (Puslit BKLH) yang bekerjasama dengan Kementrian Lingkungan Hidup, Badan Lingkungan Hidup di Provinsi DIY, kabupaten, dan kota.

\section{Keterlibatan lingkungan (environmental involvement)}

Di Universitas Negeri Yogyakarta tidak terdapat unit atau badan lingkungan hidup yang secara khusus dibentuk untuk menangani masalah lingkungan. pembangunan sarana dan prasarana di UNY tidak dilanjutkan dengan perawatan, sehingga banyak fasilitas, sarana, dan prasarana yang tidak terawat dan kotor. Untuk itu UNY perlu mengalokasikan dana yang lebih khusus untuk mengatasi masalah lingkungan. Selain itu, UNY juga perlu berinvestasi untuk mendukung implementasi green accounting berbasis USR di UNY. Progam-progam lingkungan yang di UNY juga belum maksimal, dan dirasa masih kurang, untuk Universitas yang berjagon "green and clean university". Studi keselamatan tidak semua fakultas dan jurusan mengimplementasikannya. Terkait design kurikulum dan standar kompetensi, UNY tidak mewajibkan setiap fakultas untuk menerapkan. Kecenderungan data pada keterlibatan lingkungan ada pada kategori rendah dikarenakan banyak komponen atau kondisi yang Universitas Negeri Yogyakarta masih kurang dan bahkan tidak ada.

\section{Laporan lingkungan (environmental reporting)}

Universitas Negeri Yogyakarta tidak memliki laporan kinerja terkait lingkungan, sehingga tidak ada laporan pertanggungjawaban yang secara transparan dipublikasikan dan diterbitkan secara kontinyu mengenai kinerja dan dana yang dikeluarkan terkait lingkungan.

Audit Lingkungan (environmental auditing)

Di Universitas Negeri Yogyakarta tidak terdapat laporan lingkungan dan keterlibatan lingkungannya pun rendah, bisa dipastikan UNY juga tidak memiliki Satuan Pengawas Internal yang memiliki kompeten khusus untuk mengaudit progam-progam, dana, dan kinerja lingkungan yang dilaksanakan UNY.

\section{SIMPULAN DAN SARAN}

\section{Simpulan}

Berdasarkan data yang sudah diperoleh dan hasil analisis yang telah dilakukan, maka kesimpulan dari penelitian ini adalah:

1. Kepedulian lingkungan pihak Universitas Negeri Yogyakarta terkait green accounting berbasis university 


\section{JURNAL NOMINAL / VOLUME III NOMOR 2 / TAHUN 2014}

social responsibility (USR) dinilai tinggi. Terbukti dengan hasil penelitian yang menunjukan $50 \%$ berada pada kecenderungan kategori tinggi.

2. Keterlibatan lingkungan UNY terkait green accounting berbasis USR dinilai rendah. Hal ini dibuktikan dengan penelitian yang menunjukan lebih dari setengah responden berada pada kategori rendah, yaitu sebanyak 26 responden atau $52 \%$.

3. Pelaporan lingkungan di UNY berada pada kecenderungan kategori rendah, hal ini dibuktikan $42 \%$ responden berada pada kategori rendah.

4. Audit lingkungan berada pada kategori rendah, hal ini dibuktikan $44 \%$ responden berada pada kecenderungan kategori yang rendah

\section{Saran}

Berdasarkan hasil penelitian yang telah dilakukan, peneliti memberikan saran sebagai berikut:

1. Pihak universitas perlu lebih memperhatikan komunitas lingkungan di UNY dan juga berkerjasama dalam pencapaian tujuan jargon "green and clean university".

2. Universitas Negeri Yogyakarta perlu merealisasikan bentuk kepedulian terhadap lingkungan dengan aksi nyata seperti membentuk unit khusus yang menangani lingkungan hidup di UNY.
3. Universitas Negeri Yogyakarta perlu meiliki progam khusus terkait lingkungan untuk merealisasikan jargonnya green and clean university.

4. Universitas Negeri Yogyakarta hendaknya mengalokasikan anggaran dana khusus untuk menangani permasalahan lingkungan dan menelusuri kos-kos aktivitas terkait lingkungan hidup. Selain itu UNY juga perlu melakukan investasi terkait lingkungan hidup di sekitar UNY.

5. Design kurikulum, standar kompetensi, dan proses belajar mengajar di UNY perlu dibuat dengan lebih memperhatikan aspek lingkungan.

6. UNY perlu memiliki laporan kinerja lingkungan untuk mewujudkan green and clean university. Laporan kinerja lingkungan yang mengalokasikan biaya khusus untuk lingkungan hidup yang dilaporkan secara kontinyu dan dipublikasikan.

7. UNY perlu melakukan audit terkait lingkungan, untuk itu UNY perlu memiliki Satuan Pengawas Internal yang berkompeten dalam bidang lingkungan hidup untuk memastikan bahwa progamprogam lingkungan serta alokasi anggran khusus untuk lingkungan yang telah dilakukan UNY berjalan efektif dan efisien. 


\section{DAFTAR PUSTAKA}

Bebbington, J. (1997).’Engagemenr, education, and sustainability". Accounting, Auditing, and Accountibility Journal. Vokume 10. No.3., pp. 365-381.

Dunk, A. S. (2002). "Product Quality, Environmental Accounting and Quality Performance". Accounting, Auditing, and Accountibility Journal.Vol. 15, No. 5, pp. 719-732. MCB Up Limited.

Gendro Wiyono. (2011). Merancang Penelitian Bisnis Dengan Alat Analisis SPSS 17.0 dan SmartPLS 2.0”. Yogyakarta: STIM YKPN.

Imam, Ghozali. (2005). Aplikasi Analisis Multivariate dengan Progam IBM SPSS 19. Semarang: Universitas Diponegoro.

Gray, R. and Laughlin, R. (1991). "Editorial", Accounting, Auditing, andAccountibility Journal, Vol. 4, No. 3, pp. 1-4.

Joko Susilo. (2008)."'Green Accounting Di Daerah Istimewa Yogyakarta: Studi Kasus Antara Kabupaten Sleman dan Kabupaten Bantul”. JAAI. Vol. 12, No. 2. Hlm. 149-165.

Lindrianasari. (2007). "Hubungan antara Kinerja Lingkungan dan Kualitas Pengungkapan Lingkungan dengan Kinerja Ekonomi Perusahaan di Indonesia”. JAAI. Vol. 11, No. 2.
Maylia Pramono Sari dan Paulus Basuki Hadiprajitno. (2013). "Pengawasan Implementasi Green Accounting Berbasis University Social Responsibility Di Universitas Negeri Semarang Serta Studi Komparasi Universitas Se-Kota Semarang”. Jurnal Akuntansi dan Auditing. Vol. 9, No. 2. Hlm. 169-198.

Mengenal UNY Lebih Dekat (2012). Yogyakarta: Bagian Informasi Biro Akademik, Kemahasiswaan, dan Informasi (BAKI).

Mobus, J. L. (2005). "Mandatory Environmental Disclosure in Legitimacy Theory Countext". Accounting, Auditing, and Accountibility Journal, Vol. 18, No. 1, pp. $492-517$.

Ramdhan Ardhiansyah. (2012). “Analisis Corporate Social Responsibility Studi Kasus PT Sari HusadaYogyakarta". Laporan Penelitian. UNY.

Sugiyono. (2001). Metode Penelitian Bisnis. Bandung: Alfabeta.

Sugiyono. (2010). Statistik Untuk Penelitian. Bandung: Alfabeta.

Suharsimi, Arikunto. (1991).Prosedur Penelitian Suatu Pendekatan Praktik. Jakarta: Melton Putra.

Suharsimi, Arikunto. (2009). Prosedur Penelitian Suatu Pendekatan Praktik. Jakarta: Melton Putra. 
JURNAL NOMINAL / VOLUME III NOMOR 2 / TAHUN 2014

Wiedmann, T. and Manfred, L. Yousef F. H. (2003). "Green Accounting in (2006).’Third Annual International Developing Countries: The Case of Sustainableability- Creating the U.A.E and Jordan". Manajerial

Culture". 15-16 November 2006, Finance. Vol. 29, No. 8. Perth, Scotland. 